\title{
ECONOMIC EVALUATION OF SELECTED AGRICULTURAL POLICY INSTRUMENTS IN THE LIGHT OF THE MODEL OF OVERPRODUCTION ON THE CEREAL MARKET
}

\author{
MARIUSZ DACKO \\ ALEKSANDRA PEONKA
}

\begin{abstract}
Along with the socio-economic development, agriculture has a natural tendency to increase productivity. Its effect is unfavourable for farmers agricultural overproduction. In this situation, the relatively constant food needs of individual societies are able to be met by an ever smaller number of farms. Prices of agricultural products show a declining trend, which at constant or rising costs incurred by farmers leads to the unfavourable phenomenon of opening of price scissors. Under such circumstances, a growing percentage of households are at risk of bankruptcy. Among farmers, there is even more pressure to improve productivity perceived individually as a way to improve the financial situation of the farm. This is how the vicious circle closes, because further productivity growth will result in even lower prices in the future. In the struggle against overproduction and its consequences, governments decide to subsidize agricultural prices, agricultural income, set production quotas or adopt set-aside policies. This paper asseses the effects of these forms of intervention on cereal producers activity, using the system dynamics method of Bossel (2007). The presented model is a great simplification of the reality, but it allows us to make interesting observations. It provides a multi-faceted look at the social costs and benefits of selected agricultural policy instruments.
\end{abstract}

Keywords: agriculture, cereal market, overproduction, agricultural policy, dynamic model.

JEL codes: Q12, Q14, Q18, G38.

Dr inż. Mariusz Dacko, Uniwersytet Rolniczy im. Hugona Kołłątaja w Krakowie, Wydział Rolniczo-Ekonomiczny, Instytut Ekonomiczno-Społeczny, Zakład Ekonomiki i Organizacji Rolnictwa; al. Mickiewicza 21, pok. 208, 31-120 Kraków (mariusz.dacko@urk.edu.pl).

Dr inż. Aleksandra Płonka, Uniwersytet Rolniczy im. Hugona Kołłątaja w Krakowie, Wydział Rolniczo-

-Ekonomiczny, Instytut Ekonomiczno-Społeczny, Zakład Ekonomiki i Organizacji Rolnictwa; al. Mickiewicza 21, pok. 208, 31-120 Kraków (aleksandra.plonka@urk.edu.pl). 


\section{Introduction}

The modern theory of economics includes a well-established view that the market mechanism, despite many undisputed advantages, is biased by many imperfections. Its unreliability manifests itself in, inter alia, the socially unacceptable distribution of resources and revenues, a tendency to omit external costs or deepen the unequal rate of economic development. It was, therefore, concluded that it is the task of the state to take intervention measures which will correct the shortcomings of the market mechanisms by increasing the efficiency of the economy on a general scale, stabilising it and reducing excessive inequalities in the distribution of the social product (Adamowicz, 2009). However, multifaceted analysis of the real effects of pursuing a specific agricultural policy can give rise to reasonable questions about the efficiency of the instruments used and their optimal form and scope. How would the agricultural sector evolve without state interference or in the face of its radical reduction? In the economists' community, these issues still give rise to numerous discussions and controversy, since it is difficult to clearly identify and estimate the costs and benefits of leaving agriculture "alone" and the measures that would correct its functioning. Although the costs of interventionism in agriculture are enormous, it is widely used in many countries around the world. Its nature, scope and forms of support depend mainly on the level of economic development of the country concerned, the objective the country sets for itself ad its previous experience and conditions specific to that section of the economy (Biernat-Jarka, 2011).

The objective of this paper is to try to take a broader, systemic look at the selected instruments of the state agricultural policy geared towards regulating the production volume of cereals (wheat). The study used a simulation model based on the Bossel concept (2007) allowing to analyse, in the perspective of 20 years, the potential effects of both passive and active policy of the state to support cereal prices, subsidise income, impose production quota on farmers or establish the requirement to set aside a part of farmland.

The problem being addressed is important and up-to-date - the various forms of state intervention in the functioning of the agricultural sector have now become an integral feature of virtually every market economy. We often tend to marginalise the fact that in systemic terms these forms are risky interference in the very complex system, which violates the dynamic processes occurring in this system and enforcing the search for new equilibrium which is still unknown. Over time, they may reveal unintended and undesirable effects which should be taken into account in the economic calculations of costs and benefits. Therefore, the issues of selecting the given agricultural policy instrument are worth considering with support of system dynamics models, taking into account the interaction of important factors in longer term. The following simple model of overproduction in the cereal market matches this philosophy. 


\section{Genesis of interventionism in agriculture}

The birth of modern interventionism falls on the 1920s. The author of the interventionism concept was Keynes, who, after the outbreak of the Great Depression, indicated that only the creation of an economic system supported by the state could allow to eliminate crises and would stimulate the economy by putting it on the path of development (Orłowska and Pangsy-Kania, 2003). Since then, the states have systematically expanded (and they still do) their impact on the economic development process and its stability, and the instruments and methods of regulating the economy are subject to constantly evolving (Zagóra-Jonszta, 2006).

The active state policy in the agricultural sector is defined in the Polish literature as interventionism in agriculture or agricultural policy (Przygodzka, 2006). According to Wilkin (ed.) (1998), interventionism in agriculture is a form of activity of the state aimed at correcting, complementing, limiting or strengthening the market mechanism in agriculture. Tomczak (1994, p. 372) defines interventionism in agriculture as a "basic, general and one of many instruments to pursue a specific economic policy towards farms, agriculture, agribusiness and rural areas". In turn, the agricultural policy he defines as ,, a policy for the development of agriculture and rural areas". According to Zegar (1998, p. 566), agricultural policy consists in "formulating objectives and selecting the means to achieve these objectives in the given circumstances". Thus, the agricultural policy may seem to be a broader concept, covering interventionism. In practice, these concepts are used interchangeably, despite their formal distinction (Przygodzka, 2006).

According to Stiglitz (1987), the main reasons for state intervention in agriculture are the incompleteness and imperfection of agricultural markets. Wilkin (2003) is of a similar opinion, substantiating the need for interventionism with farm income problems. Adamowicz (2009) sees the basis of interventionism in agriculture in the specific characteristics of the food demand (i.e. the limited sale and increasing supply of agricultural products), income problems of farmers and, above all, in the need to counteract their excessive disparities. Among the most important conditions of intervention in the agricultural sector Klawe (1981) includes the fact that the agricultural production is not able to adapt rapidly and flexibly to the ever-changing market situation. Also, the considerations of other theorists (e.g. Harris, 1947; Irwin, 2009) point to the need to pursue intervention in agriculture mainly for this reason.

Michałek (1989) considers the issue of insufficient and unstable farm income, which is the main reason for pursuing the specific agricultural policy by the highly developed countries. In his opinion, in the highly developed countries the dynamics of demand for agricultural goods is relatively low, which is linked to the effect of Engel's law. In addition, the labour productivity growth rate in agriculture in the post-war period was higher than in other sectors of the economy. As a result, despite the outflow of the population to work outside of agriculture, in most developed countries, the global dynamics of food production was higher than the rate at which the demand for these goods increased. The overproduction of agricultural 
products resulted in a slower rise in their prices in confrontation with a rise in prices of other goods, especially the means of production (opening of the price scissors). The unfavourable economic situation of farmers can be further aggravated by the slow outflow of excessive labour force from agriculture.

An important problem of modern agriculture is the redistribution of value added in long supply chains, as highlighted by Czyżewski, Poczta and Wawrzyniak (2006). The price of food is to the greatest extent created not by the agricultural costs of its production, but rather by markups of intermediaries the closest to the consumer. Kwaśnicki (2010) notes that this observation become the cornerstone for radical amendments to the agricultural policy in New Zealand. In many countries, the economic surplus developed in agriculture is still undeservedly taken over by other economic sectors (Czyżewski (ed.), 2007). Hence according to Kowalski and Rembisz (2005), the state should intervene in the sphere of input-output flows, by correcting the transfers of value added produced and not implemented by farmers.

In the EU policy, there is a well-established view that agriculture, being the first link in the food chain, is one of the sectors of the economy particularly sensitive to external impacts - and, therefore, requires public support. It is stressed that agriculture, despite the decreasing share in the formation of GDP, still plays a very important role in the national economy, as a sector of strategic importance from the point of view of the food needs of the society (Majewski and Ziętara (ed.), 2009). These aspects underlie the to development of the Common Agricultural Policy in 1958. This policy, being one of the most advanced forms of the state impact on agriculture and rural areas since its inception to date, has been raising a lot of controversy, often triggering the words of bitter criticism. According to Wilkin (2017), it petrifies the smallholder state by impeding the flow of land from worse to better, more rational users ${ }^{1}$. However, particularly difficult to accept are the high costs generated by agricultural support under the CAP. Kwaśnicki (2010) notes that in 2008, the EU-27 subsidies accounted for more than 1/4 of the agricultural production value, and the EU producers of beef and veal received more than half of their income in a form of government transfers. When such solutions are applied, it is not surprising that the CAP is the most expensive EU policy which consumes several tens of millions of EUR every year. However, these amounts in various forms of support go mainly to large agricultural enterprises, which account for less than $1 / 5$ of all agricultural producers operating in the EU. As Góral notes (2017), agriculture which provides for only few percent of the EU citizens, consumes as much as $38 \%$ of the EU budget. Góral does not negate unequivocally the need for intervention in agriculture, but in an interesting way considers a situation where subsidies are abandoned: "some farmers would probably refresh their entrepreneurial skills and begin to analyse the information coming from the market. They would count each zloty of their costs and manage resources in an efficient manner. The prices of land

${ }_{1}$ http://www.polskieradio.pl/42/5202/Artykul/1782502,Polityka-rolna-porazki-i-sukcesy (access date: 12.10.2017). 
would become real and start depending on the profitability of the agricultural production.”. Kwaśnicki (2010) is more radical on the issue stating that the aid to farmers in the economically developed countries distorts the structure of trade and prices of agricultural products and adversely affects the food quality. What is more, the experience of New Zealand has shown that subsidisation of agriculture has also become detrimental to other areas of socio-economic life and even to the state of the natural environment.

\section{Outline of the problem and study methodology}

Against the backdrop of the enormous social costs of supporting agriculture and their unpredictable effects going far beyond this sector, the need for simulation models enabling a multifaceted assessment of the agricultural policy instruments is basically undisputable. So far, dynamic simulation models were used in various sectors of the economy. They are known for their implementations, especially in trade, industry and in management of organisations. However, in agriculture and environmental protection, they are not too popular, although as shown by Dacko (2015) and Dacko and Bielecka (2015), dynamic models of systems could help better understand important processes and facilitate the search for appropriate solutions in pursuing the effective agricultural policy.

The model was developed in the Vensim PLE 7.1 programme by Ventana. It used 3 cumulative variables (resources), 3 streams, and 44 auxiliary variables. The model was subjected to many modifications due which it was possible to control the value of 24 different simulation parameters, including: initial number of farms, their average annual yield (t/ha) and potential sowing area (ha). It was also possible to determine the annual demand for wheat grain $(\mathrm{t})$ and its initial unit price (EUR/t). Other parameters were defined by modifying the Bossel (2007), model so that it was possible to observe the impact of various agricultural policy tools on the prices, income of farms, their number and average size of the various farm policies over a period of 20 years. The model is documented by the dynamic equations generated in the Vensim programme (Table 1) and the flow diagram (Fig. 1). Table 2 shows the list of modifiable model parameters and their default values. The information included in the tables and the flow diagram allows us to reproduce the model and run it in the Vensim programme.

\section{Description of the model}

Using the system dynamics, Bossel (2007) considers, in a perspective of 20 years, a hypothetical situation of 100 thousand farms specialised in the cultivation of wheat and having a potential total sowing area of 5 million ha. The author focuses on the phenomenon of overproduction, resultant change in the agrarian structure and the financial situation of farmers, and on attempts to control those effects by the state. The total cereal production is a resultant of the action on three factors variable over time (Table 1, equation 15): number of farms, their average size (ha) and their average annual yield (t/ha). In the market economy, the production should be adjusted to the demand since the lack of equilibrium 
in this respect results in a price which is too high for the buyer or too low for the seller. For the farmer (one of 100 thousand other producers), the price is an external factor - as an individual he does not have any impact on it, he can only try to adapt to it and in extreme cases (as envisaged by the model) - go bankrupt. The adaptation may consist in increasing the scale of production and/or improving its performance. However, these individually justified solutions can together generate an effect intensifying the overproduction and ultimately even aggravating the situation of producers.

This phenomenon is a part of the archetypes known in the theory of systems, which will also be confirmed by the results of the simulations performed. The fight against overproduction reminds the systemic mechanism of harmful drugs (Senge, 2006). However, the very formation of overproduction seems to be subject to the tragedy of the commons (Dacko and Bielecka, 2015), first described by Hardin (1968). In this case, the system limitation is the market absorptivity where there is the demand for the specific quantity of grain - preferably without surpluses. Using the system dynamics, it has already been shown that also in agriculture the only effective way to overcome this problem is the interoperability of the system participants (Dacko, 2015). By acting alone, no farmer will solve the problem of overproduction. We should mention that this situation has occurred in New Zealand, where, paradoxically, farmers themselves (system participants) have become solidary promoters of systemic solutions, which consisted in departing from the harmful, in their opinion, subsidisation of the agricultural production (Kwaśnicki, 2010). 
Table 1

Equations of the model dynamics as generated in the Vensin programme

\begin{tabular}{|c|c|c|}
\hline No. & Content of the equation & Unit \\
\hline 1 & $\begin{array}{l}\text { Direct income support }=\text { amount of income support * PULSE } \\
\text { (moment of introducing income support, period of applying income support) }\end{array}$ & EUR \\
\hline 2 & $\begin{array}{l}\text { Unit production costs =WITH LOOKUP (productivity, } \\
([(0,0)-(12.5,270)],(0,50),(2.5,60),(5,90),(7.5,130),(10,180),(12.5,270)))\end{array}$ & $\mathrm{EUR} / \mathrm{t}$ \\
\hline 3 & current price $=$ initial price $*$ impact of relative supply on price & $\mathrm{EUR} / \mathrm{t}$ \\
\hline 4 & relative income $=$ average net farm income/expected income & - \\
\hline 5 & $\begin{array}{l}\text { farm size effect }=\text { WITH LOOKUP }(\text { size of farms } \\
([(0,0)-(500,2)],(0,1.2),(25,1.1),(50,1),(100,0.9),(1000,0.8),(2000,0.8))\end{array}$ & - \\
\hline 6 & $\begin{array}{l}\text { total production costs }=(\text { unit production costs } * \text { farm size effect }+ \text { taxes or subsidies }) * \\
\text { production }\end{array}$ & EUR \\
\hline 7 & $\begin{array}{l}\text { annual costs of support for agriculture }=\text { direct income support } * \text { number of farms }+ \\
\text { (price support - taxes or subsidies) } * \text { production }\end{array}$ & EUR/year \\
\hline 8 & total costs of support for agriculture $=$ INTEG (annual costs of support for agriculture, 0 ) & EUR \\
\hline 9 & number of farms = INTEG (farm bankruptcy rate, 100000) & farm \\
\hline 10 & $\begin{array}{l}\text { productivity limits }=\text { natural productivity limit }- \text { productivity limit } * \text { PULSE } \\
\text { (moment of introducing limits, period of using limits) }\end{array}$ & t/ha \\
\hline 11 & $\begin{array}{l}\text { taxes or subsidies }=\text { amount of taxes or subsidies } * \text { PULSE } \\
\text { (moment of introducing taxes or subsidies, period of using taxes or subsidies) }\end{array}$ & $\mathrm{EUR} / \mathrm{t}$ \\
\hline 12 & relative supply $=$ production $/$ demand for cereals & - \\
\hline 13 & $\begin{array}{l}\text { set-aside policy }=\text { share of set-aside land * PULSE (moment of introducing set-aside policy, } \\
\text { period of using set-aside policy) }\end{array}$ & - \\
\hline 14 & $\begin{array}{l}\text { demand for cereals }=\text { initial demand } *(1+\text { RAMP }(\text { change in demand, moment of change in } \\
\text { demand, 20) }\end{array}$ & $\mathrm{t}$ \\
\hline 15 & production $=$ number of farms $*$ size of farms $*$ productivity & $\mathrm{t}$ \\
\hline 16 & average net farm income $=($ farm net result $/$ number of farms $)+$ direct income support & EUR \\
\hline 17 & farm revenues $=($ impact of relative supply on price $*$ initial price + price support $) *$ sale & EUR \\
\hline 18 & sale = IF THEN ELSE (demand for cereals<production, demand for cereals, production) & $\mathrm{t}$ \\
\hline 19 & farm bankruptcy rate $=$-impact of relative income on farm bankruptcy $*$ number of farms & farm/year \\
\hline 20 & size of farms $=(1$-set-aside policy $) *$ potential sowing area/number of farms & ha \\
\hline 21 & $\begin{array}{l}\text { impact of relative income on tendencies to change productivity }=\text { WITH LOOKUP } \\
\text { (relative income, }([(0,-0.1)-(2,0.3)],(0,-0.1),(0.2,-0.1),(0.4,-0.075),(0.5,0),(0.6,0.15) \text {, }\end{array}$ & 1/year \\
\hline
\end{tabular}

$(0.7,0.2),(0.8,0.2),(0.9,0.1),(1,0.05),(1.5,0.02),(2,0),(5,0)))$

22 impact of relative income on tendencies of farms to go bankrupt $=$ WITH LOOKUP (relative

income $([(0,0)-(2,0.5)],(0,0.4),(0.3,0.15),(0.5,0.08),(0.8,0.02),(0.9,0.01),(1,0),(2,0),(5,0))$

$1 /$ year

23 impact of relative supply on price $=$ WITH LOOKUP (relative supply, $([(0,0)-(5,20)],(0.2,15)$, $(0.5,5),(0.8,2),(1,1),(1.2,0.8),(1.5,0.5),(2,0.3),(5,0.3)))$

24 price support $=$ government price support $*$ PULSE (moment of introducing price support, period of using price support)

$\mathrm{EUR} / \mathrm{t}$

25 productivity $=$ IF THEN ELSE (potential productivity $>$ productivity limits, productivity limits, potential productivity)

26 potential productivity $=$ INTEG $($ change in productivity, 5 )

t/ha

t/ha

27 farm net result $=$ farm revenues-total production costs

EUR

28 change in productivity $=$ impact of relative income on tendencies to change productivity $*$ potential productivity * (1-(potential productivity /natural productivity limit))

t/ha

Source: own study based on Bossel (2007). 
In the Bossel model, the annual volume of demand for wheat (25 million tonnes) was described by the constant parameter "initial demand". However, it was considered that the model would be more interesting if it allowed to assess the developments in the face of the ever-changing demand for cereals. Therefore, modifications were made to enable the free definition of possible changes in the "initial demand" using the parameters "change in demand" and "moment of change in demand" (Table 2, Parameters 1, 2, 13).

For the farmer, the price he receives on the market for his product is of major importance. Price in the market economy is a part of the game between the demand and supply. Therefore, when the resultant "relative supply" (i.e. the quotient of the production and the demand for cereals) indicates a shortage of the production in relation to the existing needs (i.e. when it is less than 1), the "current price" will rise. In the model, in fact, it is dependent on the graphically defined variable "impact of relative supply on price" (Table 1, equation 23). For the same reasons, in the case of the production surplus over the demand, the "current price" will fall. This price will not be adjusted only if the "production" is equal to the „demand for cereals".

The result of overproduction, which is a major problem and the essence of this model, is the price fall, which usually leads to an increase in the share of farms getting into financial difficulties. In this situation which is disadvantageous for farmers, the government can choose "price support" with a purpose of their stabilisation or deliberate change. Thanks to modifications made, the model allowed not only to determine the amount of this support ("price support amount"), but also to choose the moment of its launch and its duration ("moment of introducing price support", "period of using price support"). The presented model thus allows for the simulation of state intervention boiling down to the rule: when, in the face of overproduction, the "average net farm income" becomes too low, the unit price which farmers receive per tonne of wheat may be in a specific moment raised by "price support" by a specific amount for a given period of time.

Depending on the production surplus or deficit, the sale of wheat may correspond either to the volume of demand or the volume of production. According to the diagram, the "sale" determines "farm income" (Fig. 1). These revenues, after deduction of "total production costs", constitute the "net result of farms". This result, divided by "number of farms" may be increased by possible grants ("direct income support"), forming "average net farm income" (Table 1, equation 16).

The Bossel model estimates the "total production costs" which farmers-cereal producers incur during their activities. These costs are a function of the "production" volume, "unit production costs" and "farm size effect". "Unit production costs" are defined as the graphical "productivity" function (Table 1, equation 2). 


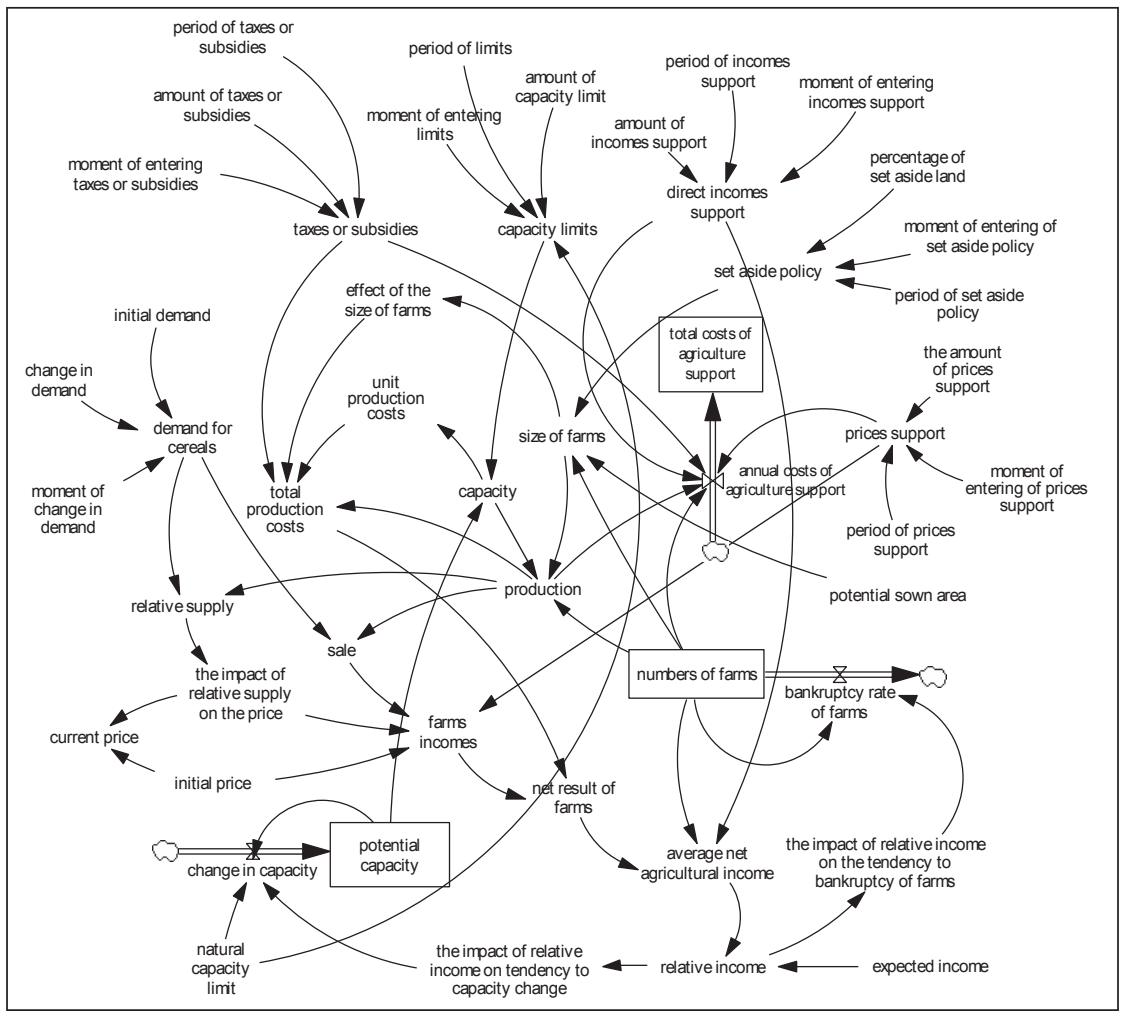

Fig. 1. Flow diagram of the model generated in the Vensim programme.

Source: own study based on Bossel (2007).

The relationship between the productivity change and the change in the unit costs incurred is non-linear. The increase in the low productivity can result in a relatively low increase in costs. The higher is the productivity of the average farm, the higher are the unit costs it must incur in order to further improve this productivity.

Based on Bossel, it was assumed that the unit cost of producing 1 tonne of wheat grain will be representative of the farm with an area of 50 ha. The graphically defined variable "farm size effect" allowed to include a decrease in the unit production costs along with an increase in the area of farms (Table 1, equation 5).

The "total production costs" (Table 1, equation 6) may also change under the influence of taxes introduced by the state (e.g. on the means of production) or grants. In the model, they are expressed in relation to 1 tonne of grain produced using the variable "taxes or subsidies".

A reasonably acting farm managers make their decisions while seeking to achieve economic success (Sroka and Dacko, 2010). The measure of this success is "relative income" arising by referring "average net farm income" to "expected income". If average income of the wheat producer proves to be lower than expected, there will be a pursuit for improving the productivity. The impact of relative income on ten- 
dencies to change the productivity (Table 1, equation 21) is non-monotonic: the tendency to improve the productivity is low in situations where "relative income" is 1.0. It decreases to zero along with the further improvement in the farmer's financial situation. A strong pressure on the productivity improvement occurs when "relative income" is lower than 1.0 but not lower than 0.7 . The productivity can be increased only up to its natural limit (adopted at $10 \mathrm{t} / \mathrm{ha}$ ) or to the level determined by the government limits (production quotas). With a further decrease in "relative income", the tendency to improve the productivity is becoming lower and below the level of 0.4 it is already a negative number. In such a difficult situation, farmers will not only lack motivation, but financial resources to improve the productivity.

The volume of "relative income" also affects the tendency of farms to go bankrupt - the lower is "relative income", the higher is the share of farms at risk of going bankrupt (Table 1, equation 22). The phenomenon of bankruptcy disappears when average income of wheat producers is equal to or exceeds expected income.

According to the notation of equations and model parameters, at the initial moment of the simulation (i.e. 2015), 100 thousand farms specialising in wheat production operated on the market. Those farms had a total area of 5 million ha. The average farm size at the initial moment was 50 ha. The annual demand for wheat grain was at the level of 25 million tonnes and its initial price was set at EUR 160 per t. Expected income was assumed at the level of EUR 30 thousand/year.

Using the model, we analysed the course and effects of overproduction of wheat grain with various scenarios of state intervention. We assessed the efficiency and costs of this intervention in the perspective of 20 years.

\section{Results of the model}

The first scenario shows the simulation results for the default parameter setting, i.e. no state intervention in the operation of cereal farms (Table 2, parameters 14 to 22 are set to 0 ).

With the initial price of EUR 160 per t, average net farm income was not only significantly lower than expected income (EUR 17,500), but it also abruptly decreased at the very beginning of the simulation (Table 3). By trying to improve their income, farmers take individual measures to improve productivity, thus leading to the growing overproduction. As a result, the farm bankruptcy rate is growing, accompanied by a tendency to land concentration. After an initial sudden decrease, average net farm income is approximately constant, as the number of farms decreases while their average size increases. After 20 years, what is left from 100 thousand farms with an average area of 50 ha are 21 thousand farms with an average area of 234 ha. In the absence of public intervention, the social costs of agricultural support were admittedly zero, but the costs appeared elsewhere: $80 \%$ of farms went bankrupt. Those that survived were converted into large farms. But the market is still struggling with the economic problem of overproduction of wheat with its increasingly lower price. A process of strong land concentration is initiated which may be accompanied by a number of adverse social and ecological effects. 
Table 2

Modifiable model parameters

\begin{tabular}{|c|c|c|c|}
\hline No. & Name of the parameter & Default setting & Unit \\
\hline 1 & initial demand & $25,000,000$ & $\mathrm{t}$ \\
\hline 2 & change in demand & 0 & $\%$ \\
\hline 3 & potential sowing area & $5,000,000$ & ha \\
\hline 4 & share of set-aside land & 0 & - \\
\hline 5 & natural productivity limit & 10 & $\mathrm{t} / \mathrm{ha}$ \\
\hline 6 & initial price & 160 & $\mathrm{EUR} / \mathrm{t}$ \\
\hline 7 & expected income & 30,000 & EUR \\
\hline 8 & moment of introducing limits & 2015 & year \\
\hline 9 & moment of introducing taxes or subsidies & 2015 & year \\
\hline 10 & moment of introducing set-aside policy & 2015 & year \\
\hline 11 & moment of introducing price support & 2015 & year \\
\hline 12 & moment of introducing income support & 2015 & year \\
\hline 13 & moment of change in demand & 2015 & year \\
\hline 14 & period of using limits & 0 & year \\
\hline 15 & period of using taxes or subsidies & 0 & year \\
\hline 16 & period of using set-aside policy & 0 & year \\
\hline 17 & period of using price support & 0 & year \\
\hline 18 & period of using income support & 0 & year \\
\hline 19 & price support & 0 & $\mathrm{EUR} / \mathrm{t}$ \\
\hline 20 & productivity limit & 0 & t/ha \\
\hline 21 & amount of taxes or subsidies & 0 & EUR \\
\hline 22 & amount of income support & 0 & EUR \\
\hline
\end{tabular}

Source: as for Table 1.

Table 3

First scenario - no state intervention

\begin{tabular}{cccccc}
\hline Year & $\begin{array}{c}\text { Current price } \\
\text { (EUR/t) }\end{array}$ & $\begin{array}{c}\text { Relative supply } \\
(-)\end{array}$ & $\begin{array}{c}\text { Number of farms } \\
\text { (farms) }\end{array}$ & $\begin{array}{c}\text { Size of farms } \\
\text { (ha) }\end{array}$ & $\begin{array}{c}\text { Average net farm income } \\
\text { (EUR) }\end{array}$ \\
\hline 2015 & 160 & 1.00 & 100,000 & 50 & 17,500 \\
2017 & 152 & 1.05 & 86,417 & 58 & 15,627 \\
2019 & 147 & 1.08 & 74,215 & 67 & 15,556 \\
2021 & 143 & 1.11 & 63,699 & 78 & 15,524 \\
2023 & 139 & 1.13 & 54,656 & 91 & 15,507 \\
2025 & 135 & 1.16 & 46,857 & 107 & 15,298 \\
2027 & 133 & 1.17 & 40,074 & 125 & 15,253 \\
2029 & 131 & 1.18 & 34,258 & 146 & 15,217 \\
2031 & 130 & 1.19 & 29,277 & 171 & 15,196 \\
2033 & 128 & 1.20 & 25,011 & 200 & 15,138 \\
2035 & 127 & 1.21 & 21,360 & 234 & 15,159 \\
\hline
\end{tabular}

Source: as for Table 1. 
The second scenario shows the development of the agricultural sector in a situation of state intervention through direct income support (Table 2, parameter $12=$ 2020 , parameter $18=15$ years, parameter $22=$ EUR 20 thousand). Launching in 2020 a system of direct subsidisation of farms with an amount of EUR 20 thousand a year initially helps to stop the farm bankruptcy processes by improving the situation of the cereal producers through increasing their average net farm income (Table 4).

Table 4

Second scenario - direct income support

\begin{tabular}{cccccc}
\hline Year & $\begin{array}{c}\text { Current price } \\
(\text { EUR/t) }\end{array}$ & $\begin{array}{c}\text { Relative supply } \\
(-)\end{array}$ & $\begin{array}{c}\text { Number of farms } \\
\text { (farms) }\end{array}$ & $\begin{array}{c}\text { Size of farms } \\
\text { (ha) }\end{array}$ & $\begin{array}{c}\text { Average net } \\
\text { farm income } \\
\text { (EUR) }\end{array}$ \\
\hline 2015 & 160 & 1.00 & 100,000 & 50 & 17,500 \\
2017 & 152 & 1.05 & 86,425 & 58 & 15,626 \\
2019 & 147 & 1.08 & 74,222 & 67 & 15,556 \\
2021 & 142 & 1.12 & 68,766 & 73 & 33,021 \\
2023 & 131 & 1.18 & 68,322 & 73 & 24,977 \\
2025 & 119 & 1.26 & 60,167 & 83 & 15,133 \\
2027 & 118 & 1.27 & 51,363 & 97 & 15,160 \\
2029 & 118 & 1.27 & 43,716 & 114 & 14,857 \\
2031 & 118 & 1.26 & 37,137 & 135 & 14,884 \\
2033 & 118 & 1.26 & 31,573 & 158 & 14,916 \\
2035 & 119 & 1.26 & 26,862 & 186 & 14,945 \\
\hline
\end{tabular}

Source: as for Table 1.

Although the 15-year costs of such support will be soon EUR 15 billion, the situation of farmers improved for a short run. Over time, the economic results of farms deteriorate again. The advantages of supply over demand are not, thereby, eliminated and the price of wheat is kept at the level unacceptable for the producers. Finally, despite the implementation of the expensive scheme of direct subsidisation of agricultural activities, average net income of the wheat producer will decrease from EUR 35.5 thousand in 2020 to EUR 14.9 thousand in 2035. In these circumstances, the number of farms will be reduced to less than 27 thousand with an average area of 186 ha. The simulation result shows that the overproduction process and the accompanying bankruptcy of farms cannot be effectively prevented by the use of the direct grant system which is expensive for taxpayers.

In the next scenario, we considered the effect of state intervention consisting in launching in 2020 the system to support prices of wheat with an amount of EUR 80 per $\mathrm{t}$ (Table 2, parameter $11=2020$, parameter $17=15$ years, parameter $19=\mathrm{EUR}$ 80 per $\mathrm{t}$ ). As it turned out, also this approach only temporarily stopped problems of farmers and the decrease in the number of farms. The problem of the insolvency 
of farms returned with the accompanying tendency to increase the average farm size. The simulation showed that such intervention carried out over a period of 15 years, would cost taxpayers almost EUR 24 billion. Still, the price of grain at the end of the simulation period falls to EUR 9 per /t. In these circumstances, the number of farms decreased to 42 thousand and their average area increased to 120 ha (Table 5). Moreover, in 2035, overproduction (Table 5, relative supply: 1.39) is even larger in size than in the absence of intervention (Table 3, relative supply: 1.21 ), although its objective was to counteract this phenomenon.

Table 5

Third scenario - price support

\begin{tabular}{cccccc}
\hline Year & $\begin{array}{c}\text { Current price } \\
(\text { EUR/t) }\end{array}$ & $\begin{array}{c}\text { Relative supply } \\
(-)\end{array}$ & $\begin{array}{c}\text { Number of farms } \\
\text { (farms) }\end{array}$ & $\begin{array}{c}\text { Size of farms } \\
(\text { ha) }\end{array}$ & $\begin{array}{c}\text { Average net } \\
\text { farm income } \\
\text { (EUR) }\end{array}$ \\
\hline 2015 & 160 & 1.00 & 100,000 & 50 & 17,500 \\
2017 & 152 & 1.05 & 86,425 & 58 & 15,626 \\
2019 & 147 & 1.08 & 74,222 & 67 & 15,556 \\
2021 & 143 & 1.11 & 68,766 & 73 & 43,281 \\
2023 & 139 & 1.13 & 68,766 & 73 & 40,043 \\
2025 & 134 & 1.17 & 68,766 & 73 & 35,886 \\
2027 & 127 & 1.21 & 68,766 & 73 & 30,552 \\
2029 & 109 & 1.32 & 65,791 & 76 & 16,902 \\
2031 & 103 & 1.35 & 56,659 & 88 & 15,599 \\
2033 & 99 & 1.38 & 48,656 & 103 & 15,415 \\
2035 & 97 & 1.39 & 41,640 & 120 & 15,281 \\
\hline
\end{tabular}

Source: as for Table 1.

In the fourth scenario, we considered the impact of the set-aside policy on the phenomenon of overproduction (Table 2, parameter $10=2020$, parameter $16=15$ years). Based on Bossel (2007), we considered a situation in which $20 \%$ of the potential sowing area is excluded from the production under the set-aside policy introduced in 2020. As a result of these changes, the production is reduced. There is a clear decrease in the relative supply, which contributes to formation of a more favourable price for farmers (in 2021, it rises to EUR 256 per t). Thus, average net farm income is significantly improved (in 2021, it rises to almost EUR 51 thousand). However, this approach also does not guarantee a sustainable solution to the problem. Ten years after implementing the set-aside policy, the dynamics of the system returns to the previous trend, i.e. increase in the farm bankruptcy rate (Table 6) in view of the fall in wheat market prices. The number of producers decreased to 48 thousand with an increase of the average farm area to 83 ha. 
Table 6

Fourth scenario - set-aside policy

\begin{tabular}{lccccc}
\hline Year & $\begin{array}{c}\text { Current price } \\
(\text { EUR/t) }\end{array}$ & $\begin{array}{c}\text { Relative supply } \\
(-)\end{array}$ & $\begin{array}{c}\text { Number of farms } \\
\text { (farms) }\end{array}$ & $\begin{array}{c}\text { Size of farms } \\
\text { (ha) }\end{array}$ & $\begin{array}{c}\text { Average net } \\
\text { farm income } \\
(\text { EUR })\end{array}$ \\
\hline 2015 & 160 & 1.00 & 100,000 & 50 & 17,500 \\
2017 & 152 & 1.05 & 86,425 & 58 & 15,626 \\
2019 & 147 & 1.08 & 74,222 & 67 & 15,556 \\
2021 & 256 & 0.88 & 68,766 & 58 & 50,918 \\
2023 & 247 & 0.89 & 68,766 & 58 & 48,386 \\
2025 & 236 & 0.91 & 68,766 & 58 & 45,037 \\
2027 & 220 & 0.92 & 68,766 & 58 & 40,216 \\
2029 & 198 & 0.95 & 68,766 & 58 & 32,622 \\
2031 & 155 & 1.03 & 64,968 & 62 & 16,226 \\
2033 & 151 & 1.05 & 55,900 & 72 & 15,600 \\
2035 & 148 & 1.08 & 48,014 & 83 & 15,591 \\
\hline
\end{tabular}

Source: as for Table 1 .

In the further part of analyses, it was examined whether the situation of the producers would be improved by the regular, as from the beginning of 2020, increase in the demand for wheat grain. Let us assume that it would take place at a rate of $2 \%$ per annum, e.g. as a result of the use of grain in energy and biofuels production (Table 2, parameter $2=0.2$, parameter $13=2020$ ). Along with the increased market demand, farmers can sell more cereals, thus their income improves. Nevertheless, the number of farms and their area is not permanently stabilised over the analysed period (Table 7). Admittedly, the demand for grain increases in 2035 to 32.5 million tonnes, however, we can observe the development of the situation similar to the scenarios presented above. The overproduction still exists and results in shaping the price that is not favourable to farmers. The number of farms is reduced to 23 thousand with an increase in their average area to $216 \mathrm{ha}$. The additional simulations carried out for this scenario showed that the demand growth would have to be far greater, but then other problems would appear. For example, if the demand increased at a rate of 5\% per year, then, at the end of the simulation period, it would balance the growing productivity of cereal farms, but in the long term it would keep on exceeding it, thus contributing to the price rise disadvantageous to consumers. 
Table 7

Fifth scenario - increased demand for wheat grain

\begin{tabular}{lccccc}
\hline Year & $\begin{array}{c}\text { Current price } \\
(\text { EUR/t) }\end{array}$ & $\begin{array}{c}\text { Relative supply } \\
(-)\end{array}$ & $\begin{array}{c}\text { Number of farms } \\
\text { (farms) }\end{array}$ & $\begin{array}{c}\text { Size of farms } \\
\text { (ha) }\end{array}$ & $\begin{array}{c}\text { Average net } \\
\text { farm income } \\
\text { (EUR) }\end{array}$ \\
\hline 2015 & 160 & 1.00 & 100,000 & 50 & 17,500 \\
2017 & 152 & 1.05 & 86,417 & 58 & 15,625 \\
2019 & 147 & 1.08 & 74,215 & 67 & 15,556 \\
2021 & 146 & 1.09 & 63,699 & 78 & 18,036 \\
2023 & 143 & 1.10 & 55,194 & 91 & 18,486 \\
2025 & 141 & 1.12 & 47,817 & 105 & 18,711 \\
2027 & 141 & 1.12 & 41,331 & 121 & 19,168 \\
2029 & 140 & 1.12 & 35,723 & 140 & 19,737 \\
2031 & 140 & 1.12 & 30,884 & 162 & 20,411 \\
2033 & 141 & 1.12 & 26,711 & 187 & 21,201 \\
2035 & 141 & 1.12 & 23,121 & 216 & 22,119 \\
\hline
\end{tabular}

Source: as for Table 1 .

The last simulation concerned analysis of the effects of introducing the limit for the further intensification of production. We should recall that the total production of cereals is a resultant of three factors variable over time: number of farms, their average size (ha) and their average annual yield ( $\mathrm{t} / \mathrm{ha}$ ). Thus, the limit of the wheat production volume preventing the destabilisation of the cereal market at the number of 100 thousand farms with an average size of 50 ha should be $5 \mathrm{t} / \mathrm{ha}$. This would give the annual production of 25 million tonnes satisfying the market demand. On this basis, the last scenario considered a decision to be made by the government in 2020 on introducing the wheat yield limit of up to $5 \mathrm{t} / \mathrm{ha}$ (Table 2, parameter $8=2020$, parameter $14=15$ years, parameter $20=5 \mathrm{t} / \mathrm{ha}$ ). In practice, such an instrument could become materialised, e.g. in the government plans for sustainable agriculture, combined with a system of incentives to extensify crops and reduce the consumption of mineral fertilisers.

Creating incentives to reduce the pursuit of the productivity growth would stop a downward trend in the wheat price formation. If the limit of $5 \mathrm{t} / \mathrm{ha}$ could be maintained, the production volume would be adjusted to the market demand (Table 8). Since 2021, we are observing price stabilisation at the level of EUR 160 per t. At that price, net farm income would be lower than expected, but the pursuit of their improvement would no longer take place by the excessive intensification of production (thanks to the limit), but by its moderate scaling up. 
Table 8

Sixth scenario - government productivity limits

\begin{tabular}{cccccc}
\hline Year & $\begin{array}{c}\text { Current price } \\
(\text { EUR/t) }\end{array}$ & $\begin{array}{c}\text { Relative supply } \\
(-)\end{array}$ & $\begin{array}{c}\text { Number of farms } \\
\text { (farms) }\end{array}$ & $\begin{array}{c}\text { Size of farms } \\
\text { (ha) }\end{array}$ & $\begin{array}{c}\text { Average net } \\
\text { farm income } \\
\text { (EUR) }\end{array}$ \\
\hline 2015 & 160 & 1.00 & 100,000 & 50 & 17,500 \\
2017 & 152 & 1.05 & 86,425 & 58 & 15,626 \\
2019 & 147 & 1.08 & 74,222 & 67 & 15,556 \\
2021 & 160 & 1.00 & 68,103 & 73 & 27,244 \\
2023 & 160 & 1.00 & 66,986 & 75 & 27,780 \\
2025 & 160 & 1.00 & 66,102 & 76 & 28,220 \\
2027 & 160 & 1.00 & 65,403 & 76 & 28,577 \\
2029 & 160 & 1.00 & 64,850 & 77 & 28,866 \\
2031 & 160 & 1.00 & 64,413 & 78 & 29,098 \\
2033 & 160 & 1.00 & 64,068 & 78 & 29,284 \\
2035 & 160 & 1.00 & 63,796 & 78 & 29,433 \\
\hline
\end{tabular}

Source: as for Table 1.

In this scenario, after 15 years from the introduction of the limit, the activity is run by 64 thousand farms with an average area of 78 ha. Average net farm income achieved by the wheat producers is, though, similar to expected income, which alleviates (at least in the analysed perspective of 20 years) changes in the agrarian structure, by limiting the tendencies for excessive land concentration.

Summary and conclusions

Active agricultural policy pursued by the state is approved by both economists and politicians. Today, there is, practically, no such thing as agriculture left fully to free market game. The agricultural policy with a wide range of various instruments interferes with agricultural activities, correcting and supporting it. This is not only in the interest of farmers. Taking care of the agricultural sector is in the public interest and is important for the development of the economy. It has become necessary due to the need to protect the environment. And this is a background against which there is an urgent need to assess the size, principles, methods and tools of intervention in agriculture. What is also important is as flexible as possible action of the authorities in response to the observed (and best also anticipated) developments in the situation of agricultural production sector. Such flexibility could be ensured by using in agricultural policy the system dynamics method which was illustrated by the overproduction model on the wheat market. This method allows for a deeper understanding of the system functioning, and consequently thoroughly thought-out interference with "live economic substance".

The authors are aware that the model was a simplification of reality. It did not take into account the possibility of reprofiling the production of the farm, which in 
the reality was one of the typical adaptation actions taken before the decision on the complete abandonment of agricultural activities. The possibility of exporting the cereal surplus, being a sign of trade characteristic of open systems, was also ignored. The model could probably be extended by these and many other aspects, but then its description, together with the interpretation of the obtained results would go far beyond the limited publication framework of a scientific journal.

The overproduction model presented in this paper was based on expert knowledge about the general economic conditions of the agricultural production. In a systemic approach, such solutions are relatively frequent. System dynamics models are not always based on specific data. They can be purely theoretical and still lead to many valuable observations, if only the researcher respects and reflects the most important principles governing the real system. According to the authors, this was also the case of the analysed issue of the cereal production. It should be mentioned that a significant number of modifiable parameters open up the possibility of calibrating the model so that it could describe the actual production and realities of the given country, and then of analysing various scenarios of the functioning of cereal farms in a specified time horizon.

In the light of the obtained results, it could be concluded that leaving the cereal production alone (scenario 1) in the longer term did not give any favourable results. But such results were not obtained also by intervention in a form of financial support which was expensive for the society (scenarios 2 and 3). The improvement in the situation of farmers-cereal producers was also not provided by the analysed scenarios to increase the demand for wheat grain. Also here the tendency to increase the productivity destabilised the system. The wheat price, determining farmers' income, would be most efficiently stabilised by the weakening of stimuli forcing the pursuit of the further increase in the crop productivity (scenario 5) and this is the way to be followed by the modern agricultural policy instruments, to reconciliate the economic objectives of farmers with public welfare and environmental care. The challenges facing the agricultural policy are, in fact, changing. In the interest of societies, it is no longer just to obtain cheap industrial food. The product for which it is worth to pay becomes a good state of ecosystems used for agricultural purposes. The beneficiary of such support should not be worried about the productivity. It would get a favourable subsidy not because it owns farmland and produces a lot of food, but because of the fact that by taking care of the environment, it voluntarily and deliberately, did not take part in the pursuit of productivity. 


\section{References}

Adamowicz, M. (2009). Wymiary i cele interwencjonizmu rolnego w krajach o różnym poziomie rozwoju. In: M. Adamowicz (ed.), Wspólna Polityka Rolna Unii Europejskiej. Uwarunkowania, Mechanizmy, Efekty (pp. 13-36). Warszawa: Wydawnictwo SGGW.

Biernat-Jarka, A. (2011). Interwencjonizm państwowy w rolnictwie. Roczniki Naukowe SERiA, t. XIII (5), pp. 5-8.

Bossel,H.(2007). SystemZOO2 Simulation Models.Climate, Ecosystem, Resources. Norderstedt: Books of Demand GmbH.

Czyżewski, A. (ed.). (2007). Uniwersalia polityki rolnej w gospodarce rynkowej, ujęcie makroi mikroekonomiczne. Poznań: Wydawnictwo Akademii Ekonomicznej w Poznaniu.

Czyżewski, A., Poczta, A., Wawrzyniak, L. (2006). Interesy europejskiego rolnictwa w świetle globalnych uwarunkowań polityki gospodarczej, Ekonomista, nr 3, pp. 350-351.

Dacko, M. (2015). The Issue of Environmental Resources Management in the Light of the Model of Tragedy of the Commons - Systemic Approach. Problemy Ekorozwoju, nr 1(10)/2015, pp. 21-30.

Dacko, M., Bielecka, P. (2015). Problematyka gospodarowania zasobami środowiska w świetle systemowego archetypu tragedii dóbr wspólnych. Ekonomia $i$ Środowisko, $n r$ 2(53), pp. 10-22.

Góral,J.(2017).WPolscerolnictwoopłacasięod50hektarów.Retrievedfrom:https://www.obserwatorfinansowy.pl/forma/rotator/w-polsce-rolnictwo-oplaca-sie-od-50-hektarow/ (access data: 12.10.2017).

Hardin, G. (1968). The Tragedy of the Commons. Science, vol. 162, issue 3859, pp. 1243-1248. DOI: 10.1126 / science.162.3859.1243.

Harris, S. (1947). The New Economics: Keynes's influence on theory and public policy. New York: Alfred A Knopf.

Irwin, S.H. (2009). Devil or angel? The role of speculation in the recent commodity boom (and bust). Journal of Agricultural and Applied Economics, $n r$ 41(02), pp. 377-391.

Klawe, A.J. (1981). Interwencjonizm w rolnictwie a międzynarodowy charakter rolny. Warszawa: PWN.

Kowalski, A., Rembisz, W. (2005). Rynek rolny i interwencjonizm a efektywność i sprawiedliwość społeczna. Warszawa: IERiGŻ-PIB.

Kwaśnicki W. (2010). Subsydiowanie rolnictwa - spojrzenie liberała. Wieś i Doradztwo, nr 1-2, pp. 61-62.

Majewski, E., Ziętara, W. (ed.). (2009). Wpływ zmian we Wspólnej Polityce Rolnej na wyniki ekonomiczne gospodarstw towarowych w Polsce w perspektywie 2014 roku. Warszawa: Wydawnictwo SGGW.

Michałek, J. (1989). Międzynarodowa polityka handlowa w ramach GATT. Warszawa: Wydawnictwo Uniwersytetu Warszawskiego.

Orłowska, R., Pangsy-Kania, S. (2003). Cykle koniunkturalne - teoria, analiza i praktyka. Gdańsk: Fundacja Rozwoju Uniwersytetu Gdańskiego.

Przygodzka, R. (2006). Fiskalne instrumenty wspierania rozwoju rolnictwa - przyczyny stosowania, mechanizmy i skutki. Białystok: Wydawnictwo Uniwersytetu w Białymstoku.

Senge, P. (2006). Piąta dyscyplina. Teoria i praktyka organizacji uczacych się. Kraków: Wolters Kluwer.

Sroka, W., Dacko, M. (2010). Ocena czynników rozwoju przodujących gospodarstw rolniczych z wykorzystaniem metody drzew regresyjnych typu C\&RT. Zagadnienia Ekonomiki Rolnej nr 2(323), pp. 100-112. 
Stiglitz, J.E. (1987). Some Theoretical Aspects of Agricultural Policies. World Bank Research. Observer, vol. 2(1), pp. 43-60.

Tomczak, F. (1994). Interwencjonizm agrarny i instrumenty polityki rolnej. Ekonomista, nr 3, pp. 371-386.

Wilkin, J.(ed.).(1998). Encyklopedia agrobiznesu. Warszawa: Wydawnictwo Fundacja Innowacja.

Wilkin, J. (2003). Interwencjonizm państwowy $w$ rolnictwie: dlaczego byt, jest $i$ będzie. Dostosowanie się polskiego rynku rolnego do wymogów UE. Warszawa: IERiGŻ.

Wilkin, J. (2017). Polityka rolna: porażki i sukcesy. Retrieved from: http://www.polskieradio. pl/42/5202/Artykul/1782502,Polityka-rolna-porazki-i-sukcesy.

www.polskieradio.pl/42/5202/Artykul/1782502,Polityka-rolna-porazki-i-sukcesy (access date: 12.10.2017).

Zagóra-Jonszta, U. (2006). Rola państwa w procesie współczesnych przeobrażeń ekonomiczno-społecznych. In: D. Kopycińska (ed.), Regulacyjna rola państwa we wspótczesnej gospodarce (pp. 7-13). Szczecin: Wydawnictwo Printgroup.

Zegar, J.S. (1998). Polityka rolna. In: A. Woś (ed.), Encyklopedia agrobiznesu. Warszawa: Wydawnictwo Fundacja Innowacja. 


\title{
EKONOMICZNA OCENA WYBRANYCH INSTRUMENTÓW POLITYKI ROLNEJ W ŚWIETLE MODELU POWSTAWANIA NADPRODUKCJI NA RYNKU ZBÓŻ
}

\begin{abstract}
Abstrakt
Wraz z rozwojem społeczno-gospodarczym rolnictwo wykazuje sie naturalna tendencją do wzrostu wydajności, której efektem bywa niekorzystne dla rolników zjawisko nadprodukcji rolnej. W jej obliczu coraz mniejsza liczba gospodarstw jest $w$ stanie zaspokajać potrzeby żywnościowe społeczeństwa. Ceny produktów rolnych wykazuja się wówczas tendencją malejaca, co przy stałych badź rosnacych kosztach ponoszonych przez rolników doprowadza do tzw. rozwierania się nożyc cenowych. W takich okolicznościach rośnie odsetek gospodarstw zagrożonych problemami finansowymi, a nawet upadkiem. Ale paradoksalnie, wśród rolników może jeszcze bardziej nasilać się presja na wzrost wydajności postrzeganej indywidualnie jako sposób na poprawe sytuacji finansowej gospodarstwa. Tak zamyka się błędne koło, gdyż dalszy wzrost produktywności powoduje ukształtowanie się jeszcze niższych cen w przyszłości. W walce $z$ nadprodukcja i jej skutkami rzady decyduja sie m.in. na wspieranie cen produktów rolnych, subsydiowanie dochodów rolniczych, ustalanie kwot produkcyjnych badź przyjmowanie polityki odłogowania. W niniejszej pracy podjęto za Bosselem (2007) próbę oceny skutków takich form interwencji w działalność producentów zbóż przy wykorzystaniu metody dynamiki systemów. Prezentowany model jest uproszczeniem rzeczywistości, jednak umożliwia dokonanie ciekawych obserwacji. Pozwala na wieloaspektowe spojrzenie na koszty i korzyści wybranych instrumentów polityki rolnej.
\end{abstract}

Słowa kluczowe: rolnictwo, rynek zbóż, nadprodukcja, polityka rolna, model dynamiczny.

Accepted for print: 25.04 .2018 .

Unless stated otherwise all the materials on the website are available under the Creative Commons Attribution 4.0 International license.

Some rights reserved to the Institute of Agricultural and Food Economics - National Research Institute.

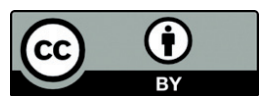

